\title{
Self and Peer Assessment of Teachers' Attitude towards Teaching
}

\author{
Ambreen Ansar1, Robina Mushtaq Rizvi1, Afsah Hussain², Ameera Nawaz², Abeera Zafar² and Ammara Fayyaz²
}

\begin{abstract}
Objective: To appraise the attitude of the teachers towards teaching and the factors affecting their attitudes, and compare self-assessed attitudes of the medical teachers with teachers in social sciences.

Study Design: Cross-sectional descriptive study.

Place and Duration of Study: Wah Medical College (WMC), Wah Cantt, from January to August 2016.

Methodology: Teachers were categorized as having positive, average, and below average attitudes on the basis of a close-ended questionnaire comprising of 32 items. All the items were ranked on 5 points Likert-scale. Questionnaires were filled by the teachers twice, first for themselves and then for their peers.

Results: There were 91 self-assessments [53 medical teachers (MT) and 38 social sciences teachers (SST)], and 59 peer assessments (31 MT and 28 SST). Overall, the attitude of teachers was average as 99 teachers $(66 \%)$ fell in this category. Out of 53 MT, $9(17 \%)$ had a positive attitude and $43(81.1 \%)$ had average attitude. Out of 38 SST, $5(13.2 \%)$ had positive attitude and $21(55.3 \%)$ had average attitude. MT self-accounted attitude was significantly higher than the SST $\left(\chi^{2}=15.975\right.$, $p=<0.001)$ in comparison to peer assessed attitude, which was equal in the two groups $\left(\chi^{2}=2.778, p=0.249\right)$. Variables significantly associated with good attitude, were female gender, junior designation and more experienced.

Conclusion: Overall teachers' attitude was average in both faculties. But the self-accounted attitude was higher among MT than SST. Teachers who are junior in qualification and designation, females, medical by profession, and more experienced need to improve their self-assessment and reflection skills.
\end{abstract}

Key Words: Assessment, Attitude, Peer, Self, Teachers.

\section{INTRODUCTION}

Society traditionally views teaching as an extremely honorable profession and regards teachers as advocates of positive societal change, who are refurbishing the education system. ${ }^{1}$ Teachers try to attune themselves to the learning environment and the students. At the same time, every teacher diversifies the educational curriculum by integrating their own opinions and experiences into the syllabi. ${ }^{2}$ Their self-efficacy play a great role in the quality of education they provide. ${ }^{3}$

Richardson combines attitudes with beliefs, and states that both "are a subset of a group of constructs that name, define, and describe the structure and content of mental states that are thought to drive a person's actions". 4 These constructs include their gender, experience, choice of teaching as a career, characteristics of learning communities and profession for example medical or otherwise. Among personal characteristics punctuality, devotion, commitment with the students, and self-effficacy are important, while amongst organizational elements team work, shared values, vision and work

1 Department of Community Medicine, Wah Medical College (WMC), Wah Cantt, Pakistan

2 House Officer, Pakistan Ordnance Factories (POF) Hospital, Wah Cantt, Pakistan

Correspondence: Dr. Ambreen Ansar, Department of Community Medicine, Wah Medical College (WMC), Wah Cantt, Pakistan E-mail: ansarambreen@gmail.com

Received: May 26, 2018; Accepted: November 12, 2018 environment are important. ${ }^{3}$ The characteristics of learning communities have an impact on teachers' attitude which determines the degree of dedication they show towards their students. ${ }^{5} \mathrm{~A}$ higher level of all these factors is essential for boosting the quality of education and enabling students to develop their abilities for achieving scholastic milestones. 6,7

Teachers should assess various aspects within themselves and in the environment that influence their teaching, and determine obstacles impeding efforts to inculcate knowledge and skills among the recipients of education. Feedbacks from trusted observers are very useful to overcome shortcomings, ,8,9 and would also help to check the element of self-enhancement.

\section{METHODOLOGY}

A cross-sectional study was conducted at Wah Medical College (WMC), Wah Cantt, from January to August 2016. Data was collected from target population of two highly organised faculties of medicine and social sciences to appraise teachers' attitude, through convenient sampling. The attitude was assessed on the basis of 32 Likert-scale questions, which were constructed in the light of the literature review and input from the supervisor. Cronbach's alpha calculated was 0.832 after the data collection.

A paper and pencil version of the scale was distributed to 12 medical departments, i.e. 100 medical teachers (MT) and 50 social sciences teachers (SST). It was explained to the participants that their participation in the 
study is voluntary, and their consents were obtained in the questionnaire. Teachers from each faculty filled one questionnaire for themselves and one for their peers. The peer to be reviewed by any faculty member was from the similar department and selected by the researcher after taking informed consent and maintaining confidentiality. The score obtained on self-constructed Attitude scale is the attitude towards teaching profession in this study. Each item was assigned a score ranging from 4 (strongly agree) to 0 (strongly disagree) for favorable items. In case of unfavorable items, the scoring range was reversed, i.e. from 0 (strongly agree) to 4 (strongly disagree). The theoretical range of attitude scores was from 0 to 128; and teachers were divided into three categories: positive attitude (score on the selfdevised scale above or equal to 101), average attitude (score: 86-100), and below average attitude (score 70-85).

Data was entered into SSPS Version 19. Mean and \pm SD was calculated to assess the overall attitude of teachers. Frequencies and percentages for agreement or disagreement in Likert-scale questions and of participants in three attitude categories were calculated. Chi-square test was applied to find an association between selfreported attitude versus gender, designation, qualification, and teaching experience. The level of significance $(\alpha)$ was taken at 0.05 .

\section{RESULTS}

Out of the 150 (100 MT and $50 \mathrm{SST}$ ) questionnaires distributed, 91 teachers (53 MT and 38 SST) returned (61\% response rate) the questionnaire on self-assessment of their attitudes. The same questionnaire was distributed to 150 teachers with the name of the peer to be reviewed by him/her from the same department for a peer assessment, out of which 59 (31 MT and 28 SST) were returned ( $39.3 \%$ response rate). The mean attitude score of all the teachers was $91.7 \pm 11.6$ which, according to operational definition, falls in averageattitude category. No significant difference was found in teachers' attitudes assessed by themselves and by their peers when compared overall $\left(\chi^{2}=1.951, d f=2\right.$, $p=0.377$ ). A significantly higher self-assessed attitudes were found in medical teachers as compared to peer assessed attitude $\left(\chi^{2}=11.698, \mathrm{df}=2, \mathrm{p}=0.03\right)$; whereas the self and peer assessment was similar in SST $\left(\chi^{2}=3.94, d f=2, p=0.139\right)$. The graphical display of positive, average, and below average attitude scores as assessed by self and peers by both types of teachers are depicted in Figure 1.

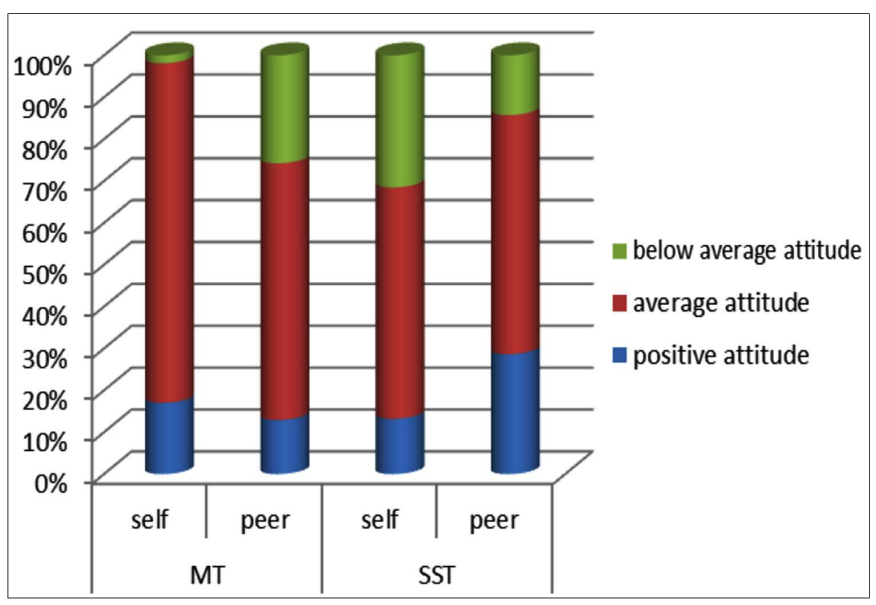

Figure 1: Bar plot of attitude assessment self and peers.

Table I: Association of self-reported teachers' attitude score with their designation, teaching experience, teaching as their first choice, gender; and the teaching institute.

\begin{tabular}{|c|c|c|c|c|}
\hline \multirow[t]{2}{*}{ Variable } & \multicolumn{4}{|c|}{ Self-assessment categories $\mathrm{f}(\%)$} \\
\hline & Positive attitude & $\begin{array}{c}\text { Above average } \\
\text { attitude }\end{array}$ & $\begin{array}{c}\text { Below average } \\
\text { attitude }\end{array}$ & $\begin{array}{l}\mathrm{X}^{2} \text { value } \\
\mathrm{p} \text {-value }\end{array}$ \\
\hline \multicolumn{5}{|l|}{ Gender } \\
\hline Male & $8(18.2)$ & $25(56.8)$ & $11(25)$ & 9.490 \\
\hline Female & $6(12.8)$ & $39(83)$ & $2(4.3)$ & 0.009 \\
\hline \multicolumn{5}{|l|}{ Designation } \\
\hline Lect \& Sr. & $4(9.5)$ & $36(85.7)$ & $2(4.8)$ & 9.319 \\
\hline Lect. AP \& above & $10(20.4)$ & $28(57.1)$ & $11(22.4)$ & 0.009 \\
\hline \multicolumn{5}{|l|}{ Teaching experience } \\
\hline$<15$ years & $11(12.9)$ & $61(71.8)$ & $13(15.3)$ & 6.298 \\
\hline$>15$ years & $3(50)$ & $3(50)$ & $0(0)$ & $0.06^{*}$ \\
\hline \multicolumn{5}{|l|}{ Qualification } \\
\hline Graduate & $3(9.7 \%)$ & $27(87.1 \%)$ & $1(3.2 \%)$ & 6.901 \\
\hline Postgraduate & $11(18.3 \%)$ & $37(61.7 \%)$ & $12(20.0 \%)$ & $0.018^{*}$ \\
\hline \multicolumn{5}{|l|}{ Teaching institute } \\
\hline Medical & $9(17)$ & $43(81.1)$ & $1(1.9)$ & 15.975 \\
\hline Social sciences & $5(13.2)$ & $21(55.3)$ & $12(31.6)$ & $<0.001$ \\
\hline \multicolumn{5}{|c|}{ Teaching as first choice } \\
\hline Yes & $9(15.3)$ & $39(66.1)$ & $11(18.6)$ & $2(6.3)$ \\
\hline No & $5(15.6)$ & $25(78.1)$ & 2.659 & $0.226^{*}$ \\
\hline
\end{tabular}

* Likelihood ratio was considered as 3 cells had expected count less than 5 
Table II: Agreement and non-agreement by the participants with the statements to assess attitude (counts and percentages).

\begin{tabular}{|c|c|c|c|c|c|c|}
\hline Statements & $\begin{array}{l}\text { Strongly } \\
\text { disagree }\end{array}$ & Disagree & Neutral & Agree & $\begin{array}{l}\text { Strongly } \\
\text { agree }\end{array}$ & Total \\
\hline \multicolumn{7}{|c|}{ I think teaching is an ennobling profession as a basis of occupational choice. } \\
\hline Response & 2 & 1 & 17 & 53 & 77 & 150 \\
\hline Percentage & 1.3 & 0.7 & 11.3 & 35.3 & 51.3 & 100 \\
\hline \multicolumn{7}{|c|}{ I joined the teaching profession to enhance my earning capability. } \\
\hline Response & 14 & 22 & 50 & 42 & 22 & 150 \\
\hline Percentage & 9.3 & 14.7 & 33.3 & 28 & 14.7 & 100 \\
\hline \multicolumn{7}{|c|}{ I like to participate in co-curricular activities as a teacher. } \\
\hline Response & 3 & 18 & 29 & 72 & 28 & 150 \\
\hline Percentage & 2 & 12 & 19.3 & 48 & 18.7 & 100 \\
\hline \multicolumn{7}{|c|}{ It is important for me to prepare my lectures daily before going to class. } \\
\hline Response & 3 & 3 & 2 & 57 & 85 & 150 \\
\hline Percentage & 2 & 2 & 1.3 & 38 & 56.7 & \\
\hline \multicolumn{7}{|c|}{ I feel comfortable delivering lectures on multimedia. } \\
\hline Response & 2 & 4 & 25 & 63 & 56 & 150 \\
\hline Percentage & 1.3 & 2.7 & 16.7 & 42 & 37.3 & \\
\hline \multicolumn{7}{|c|}{ I maintain a friendly relationship with my students. } \\
\hline Response & 3 & 5 & 13 & 80 & 49 & 150 \\
\hline Percentage & 2 & 3.3 & 8.7 & 53.3 & 32.7 & 100 \\
\hline \multicolumn{7}{|c|}{ I make effective eye contact with my students. } \\
\hline Response & 4 & 5 & 13 & 62 & 66 & 150 \\
\hline Percentage & 2.7 & 3.3 & 8.7 & 41.3 & 44 & 100 \\
\hline \multicolumn{7}{|c|}{$\begin{array}{l}\text { I enjoy participating in different educational activities offered by educational } \\
\text { organizations. }\end{array}$} \\
\hline Response & 4 & 7 & 21 & 64 & 54 & 150 \\
\hline Percentage & 2.7 & 4.7 & 14 & 42.7 & 36 & 100 \\
\hline \multicolumn{7}{|c|}{ I am devoted towards my students. } \\
\hline Response & 2 & 1 & 17 & 62 & 68 & 150 \\
\hline Percentage & 1.3 & 0.7 & 11.3 & 41.3 & 45.3 & 97.8 \\
\hline \multicolumn{7}{|c|}{ I am regular and punctual. } \\
\hline Response & 5 & 3 & 14 & 58 & 70 & 150 \\
\hline Percentage & 3.3 & 2 & 9.3 & 38.7 & 46.7 & 100 \\
\hline \multicolumn{7}{|c|}{ I am in favor of a formative assessment. } \\
\hline Response & 3 & 1 & 33 & 77 & 36 & 150 \\
\hline Percentage & 2 & 0.7 & 22 & 51.3 & 24 & 100 \\
\hline \multicolumn{7}{|c|}{ I positively accept difference of opinion of my students. } \\
\hline Response & 3 & 6 & 18 & 60 & 63 & 150 \\
\hline Percentage & 2 & 4 & 12 & 40 & 42 & 98.9 \\
\hline \multicolumn{7}{|c|}{ It is my duty to listen to and guide my students in their free time. } \\
\hline Response & 2 & 1 & 14 & 70 & 63 & 150 \\
\hline Percentage & 1.3 & 0.7 & 9.3 & 46.7 & 42 & 100 \\
\hline \multicolumn{7}{|c|}{ I feel that students show little respect for their teachers nowadays. } \\
\hline Response & 11 & 28 & 28 & 37 & 46 & 150 \\
\hline Percentage & 7.3 & 18.7 & 18.7 & 24.7 & 30.7 & 100 \\
\hline \multicolumn{7}{|c|}{ I think interactive learning is beneficial for students. } \\
\hline Response & 3 & 3 & 9 & 58 & 77 & 150 \\
\hline Percentage & 2 & 2 & 6 & 38.7 & 51.3 & 100 \\
\hline \multicolumn{7}{|c|}{$\begin{array}{l}\text { I feel responsible for grooming a student's personality as a whole in addition } \\
\text { to imparting knowledge. }\end{array}$} \\
\hline Response & 2 & 3 & 19 & 65 & 61 & 150 \\
\hline Percentage & 1.3 & 2 & 12.7 & 43.3 & 40.7 & 100 \\
\hline \multicolumn{7}{|c|}{ I agree that intelligent students should be isolated and taught separately. } \\
\hline Response & 23 & 62 & 32 & 18 & 15 & 150 \\
\hline Percentage & 15.3 & 41. & 21.3 & 12 & 10 & 100 \\
\hline \multicolumn{7}{|c|}{$\begin{array}{l}\text { I think all staff members should work together to make strategies } \\
\text { beneficial for students' learning. }\end{array}$} \\
\hline Response & 2 & 3 & 7 & 82 & 56 & 150 \\
\hline Percentage & 1.3 & 2 & 4.7 & 54.7 & 37.3 & 100 \\
\hline
\end{tabular}


Table II continue.

\begin{tabular}{|c|c|c|c|c|c|c|}
\hline Statements & $\begin{array}{l}\text { Strongly } \\
\text { disagree }\end{array}$ & Disagree & Neutral & Agree & $\begin{array}{l}\text { Strongly } \\
\text { agree }\end{array}$ & Total \\
\hline \multicolumn{7}{|c|}{$\begin{array}{l}\text { I think negative incentives (e.g. fines, reprimands etc.) have positive effects on } \\
\text { students' academic performance. }\end{array}$} \\
\hline Response & 17 & 40 & 42 & 30 & 21 & 150 \\
\hline Percentage & 11.3 & 26.7 & 28 & 20 & 14 & 100 \\
\hline \multicolumn{7}{|c|}{ Financial incentives affect my performance. } \\
\hline Response & 10 & 21 & 35 & 57 & 27 & 150 \\
\hline Percentage & 6.7 & 14 & 23.3 & 38 & 18 & 100 \\
\hline \multicolumn{7}{|c|}{ My health problems do not affect my teaching abilities. } \\
\hline Response & 18 & 14 & 29 & 51 & 8 & 150 \\
\hline Percentage & 12 & 29.3 & 19.3 & 34 & 5.3 & 100 \\
\hline \multicolumn{7}{|c|}{ I do not let my personal problems diminish my professional performance. } \\
\hline Response & 1 & 13 & 39 & 65 & 32 & 150 \\
\hline Percentage & 0.7 & 8.7 & 26 & 43.3 & 21.3 & 100 \\
\hline \multicolumn{7}{|c|}{$\begin{array}{l}\text { A friendly departmental environment encourages me to provide effective } \\
\text { educational output as teacher. }\end{array}$} \\
\hline Response & 2 & 3 & 9 & 71 & 65 & 150 \\
\hline Percentage & 1.3 & 2 & 6 & 47.3 & 43.3 & 100 \\
\hline \multicolumn{7}{|c|}{ Authoritative leadership is a hindrance in delivering maximum educational output. } \\
\hline Response & 1 & 7 & 33 & 78 & 31 & 150 \\
\hline Percentage & 0.7 & 4.7 & 22 & 52 & 20.7 & 100 \\
\hline \multicolumn{7}{|c|}{$\begin{array}{l}\text { Non-availability of basic necessities (e.g. proper ventilation, a canteen, } \\
\text { or a daycare center) negatively influences my attitude as a teacher. }\end{array}$} \\
\hline Response & 3 & 19 & 17 & 73 & 38 & 150 \\
\hline Percentage & 2 & 12.7 & 11.3 & 48.7 & 25.3 & 100 \\
\hline \multicolumn{7}{|c|}{$\begin{array}{l}\text { Hostile administrative behavior creates personal distress, which results in } \\
\text { an abysmal attitude towards students. }\end{array}$} \\
\hline Response & 5 & 16 & 29 & 62 & 38 & 150 \\
\hline Percentage & 3.3 & 10.7 & 19.3 & 41.3 & 25.3 & 100 \\
\hline \multicolumn{7}{|c|}{$\begin{array}{l}\text { I feel that a poor performance/feedback by students decreases my motivational } \\
\text { approach towards teaching them. }\end{array}$} \\
\hline Response & 2 & 26 & 36 & 60 & 26 & 150 \\
\hline Percentage & 1.3 & 17.3 & 24 & 40 & 17.3 & 100 \\
\hline \multicolumn{7}{|c|}{ Above all, I like teaching, and I am happy when I am with my students. } \\
\hline Response & 3 & 1 & 17 & 74 & 55 & 150 \\
\hline Percentage & 2 & 0.7 & 11.3 & 49.3 & 36.7 & 100 \\
\hline \multicolumn{7}{|c|}{ I am satisfied with the administration of my institution. } \\
\hline Response & 17 & 27 & 41 & 41 & 24 & 150 \\
\hline Percentage & 11.3 & 18 & 27.3 & 27.3 & 16 & 100 \\
\hline \multicolumn{7}{|c|}{ I am keen to consult books or internet sources related to my subject. } \\
\hline Response & 3 & 9 & 15 & 69 & 54 & 150 \\
\hline Percentage & 2 & 6 & 10 & 46 & 36 & 100 \\
\hline \multicolumn{7}{|c|}{ I feel a sense of achievement towards my profession. } \\
\hline Response & 2 & 5 & 22 & 64 & 57 & 150 \\
\hline Percentage & 1.3 & 3.3 & 14.7 & 42.7 & 38 & 100 \\
\hline \multicolumn{7}{|c|}{ I am satisfied with the basic facilities provided by my institution. } \\
\hline Response & 14 & 25 & 30 & 57 & 24 & 150 \\
\hline Parentage & 9.3 & 16.7 & 20 & 38 & 16 & 100 \\
\hline
\end{tabular}

Self-assessed attitudes were better for medical teachers, more experienced, female and designation-wise and qualification-wise junior teachers. The results are shown in Table I.

Table II shows that most teachers, i.e. 80 (88\%), felt proud about their profession (Q1). Punctuality by $89.1 \%$ (Q10) and hard work by $95.6 \%$ (Q4) were among the important qualities of a teachers' behavior as reported by themselves. Self-reported regularity and punctuality was not testified by the peers $\left(\chi^{2}=9.449, d f=4, p=0.04\right)$.
Similarly, regarding hard work indicated by the importance of lecture preparation by teachers, self and peer reported attitudes differ significantly $\left(\chi^{2}=12.975\right.$, $d f=4, p=0.008$ ).

\section{DISCUSSION}

The quality of any teaching programme cannot rise above the quality of its teachers. Looking from outside, teaching appears simplistic. Teachers spend their days guiding, shaping, and educating young minds to grow 
into productive and knowledgeable global citizens. Internally, there is a crush of responsibilities ranging from curriculum planning, development and implementation and administrative problems to student engagement and assessment measures that come monthly or sometimes daily. All these burdens can slowly erode the confidence and morale of even the best teachers. In addition to these errands, which all the teachers face equally, the MT has to deal with the patients as well and this is the job which they cannot afford to ignore. So, the teachers' role in medicine has extensions beyond the classroom. The proficient transmission of curricula, inculcation of accurate skills, and instillation of ethical values in the students are some important working areas for the MT to equip their students with for the upcoming challenges. Forthcoming social and political challenges have added a new dimension to this profession, which also requires specified competencies and right attitude by the teachers. 10

Teachers are the conduits of content knowledge, and their attitude makes the difference in translating their passion for teaching into students' passion for learning. To help students see the transformative potential of education from teachers' point of view, teachers must evaluate their passion, mission, and purpose for teaching preceding the content. In this study, 64\% teachers stated that teaching was their first choice as profession and both MT and SST had either positive or average attitudes, whether assessed by themselves or their peers. The positive attitudes of teachers was also observed in studies by Mehdipour, 5 Andronache, 11 and Bhalla. ${ }^{12}$ Teachers had an average attitude towards teaching in a study by Karr.13 In contrast, negative attitude of teachers was found in surveys by Issan and Hussain. ${ }^{1,14}$

Analysis of Table I indicated marked difference in the self-reported attitudes by medical and social teachers. Further analysis revealed that females and junior teachers, both in designation and qualification, were more likely to mark themselves higher in attitude scores. In contrast, teachers having more experience rated themselves high in attitude score, which is not supported by the peer-reported attitude scores. Furthermore, 100\% teachers with more than 15 years of experience, $78 \%$ of females and $81 \%$ of junior designation were MT. This implies that there is a large room of improvement for the MT. They need to spend more time on reflection and medical education activities to improve their teaching and self-analysis capabilities.

Exploring further on experience factor, which contributes significantly to forming attitude. ${ }^{15} \mathrm{~A}$ body of research showed that teaching efficiency tends to turn down with added experience ${ }^{13}$ but this study demonstrated that more experienced teachers had higher attitude scores. The authors suggest longitudinal study design rather than cross-sectional for a better understanding of this factor as attitude builds over time.

Gender also has a paramount effect on the attitude of the teacher. ${ }^{16}$ Female teachers have a positive attitude towards teaching profession, ${ }^{17,18}$ but other literatures do not support it., 19,20

Table II results imply that teachers overrated themselves and tried to convey a positive impression in this regard. This aspect needs attention from the teachers, as successful outcomes are achieved through effort and hard work, and such strategies as denying shortcomings may result in poor outcomes.

Similar to Osunde et al., this study also reveals that inadequate financial reward and delay in payment of salaries lead to atrocious attitude towards teaching profession.21 Of all the participants in this study, 42 $(45 \%)$ reported that they intend to enhance their income with the job; and such issues when minimized at the organizational level, encourage them to be more cognizant and accountable towards their contractual obligations.

Teachers displayed high levels of professional enthusiasm towards their profession according to responses on questions Nos. 6, 8, 28 and 30. The interactive learning environment, comprehensive instructional materials and diversified strategies can only be adopted by teachers having a positive attitude towards teaching profession.22,23 Majority, i.e. 72 (79.2\%), felt comfortable in using modern teaching tools like multimedia. In both faculties, $91.2 \%$ of participants agreed that they maintain a friendly relationship with their students; whereas, among their peers $78 \%$ agreed $\left(\chi^{2}=12.983, \mathrm{df}=4, \mathrm{p}=0.007\right)$. Most teachers, $77(84.7 \%)$ were devoted towards students. A significant number of participants, $75(82.5 \%)$, agreed to positively accept a difference of opinion of their students. A greater portion of the participants, 79 (86.9\%), admitted to feeling responsible for grooming a student's personality as a whole in addition to imparting knowledge. Worldwide, it is acknowledged that teachers are crucial in promoting social wellbeing of students and the attributes like friendly attitude, accepting the opinion of difference; and feeling responsible for students are vital in upholding wellbeing in students.

About $37 \%$ of teachers agreed that students show little respect to their teachers, nowadays.

A notable percentage $(92 \%, f=81)$ agreed that all staff members should work together to make strategies beneficial to students' learning. In contrast to this view, the literature says that weak ties among the employees lead to improvements and innovations in the working strategies; whereas, strong relations hinder betterment and creativity. ${ }^{22}$ The participants, who admitted authoritative leadership is a hindrance in delivering maximum educational output, were 60 (66\%). Literature also highlights the importance of contextual leadership, which 
influences teachers' attitude a great deal. As opportunity and motivation, if interact well with the ability, improve teachers' ability; and they become more willing to exert effort for the students and organization. ${ }^{24}$

A significant percentage of participants agreed that nonavailability of basic necessities $(71.4 \%, f=65)$ and poor performance/feedback by students $(43.9 \%, f=40)$, negatively influence their attitude as a teacher. These findings support others in the literature which says that a positive climate fosters a gift of positive attitude and a positive organizational climate provides the teachers a driving force to overcome challenges associated with their work. A considerable percentage $(88 \%, f=80)$ liked teaching and was happy being with students.

Similar to others, 11,15 results of this study confirmed that success in teaching field depends upon job satisfaction. Hostile administrative behaviors, poor physical surroundings, and non-availability of basic necessities create a great distress, which ultimately becomes a big obstacle to creating and maintaining a positive attitude towards the profession.

This study has some limitations like the questionnaire was novel and other reliability measures were not applied, except Cronbach's alpha. Self and peer assessment were not carried out simultaneously, which resulted in the loss of data. To examine teachers' attitudes, the specific attitude constructs to be used should be clearly conceptualized and given precise and consistent meaning.

\section{CONCLUSION}

Self-enhancement and fortification phenomenon was present in MT, especially if they were females and juniors which provide a room of improvement for the MT to work upon. They need to reflect upon their daily activities honestly and establish a more efficient communication with students.

\section{REFERENCES}

1. Issan S, Al-Nabhani H, Kazem A, Al-Ani W. Omani teachers' attitude towards teaching as a profession. Indian J Psychol Edu 2012; 1:25-40.

2. Oruc $\mathrm{N}$. The perception of teaching as a profession by Turkish trainee teachers: Attitudes towards being a teacher. Int $J$ Humanit Soc Sci 2011; 1:83-7.

3. Rimm-Kaufman SE, Sawyer BE. Primary-grade teachers' selfefficacy beliefs, attitudes toward teaching, and discipline and teaching practice priorities in relation to the "responsive classroom" approach. Elem Sch J 2004; 1:321-41

4. Richardson V. The role of attitudes and beliefs in learning to teach. Handbook of research on teacher education. 1996; 2:102-19.
5. Mehdipour Y, Balaramulu D. Students attitude toward teacher's behavior in Hyderabad universities. IJIRS 2013; 2:311-23.

6. Divya C. Attitude of teachers towards their profession and administration. Criterion Inte $J$ 2014; 5:69-74

7. Reeves DB. Reframing teacher leadership to improve your school. ASCD 2008.

8. Walsh D, King M, Griffiths A. Evaluating interviews which search for the truth with suspects: But are investigators' selfassessments of their own skills truthful ones? Psychol Crime Law 2017; 23:647-65.

9. Kwang T, Swann WB Jr. Do people embrace praise even when they feel unworthy? A review of critical tests of selfenhancement versus self-verification. Pers Soc Psychol Rev 2010; 14:263-80

10. Mashhadi HD, Pahlavan M, Kaviani M. Sociological study of motivation and its effect on Iranian teachers' learning English. J Sociol Stud Youth 2017; 7:49-60.

11. Andronache D, Bocos M, Bocos V, Macri C. Attitude towards teaching profession. Procedia Soc Behav Sci 2014; 142:628-32.

12. Bhalla A, Jajoo UN, Kalantri SP. Attitude of teachers towards teaching. J Assoc Physicians India 2002; 50:1405-8.

13. Karr $\mathrm{C}$. The attitude of teachers towards teaching reading in the content areas (Doctoral dissertation).

14. Hussain S, Ali R, Khan SM, Ramzan M, Qadeer Z. Attitude of secondary school teachers towards teaching profession. Inter J Acad Res 2011; 3:1.

15. Suja K. Interaction effect of attitude towards teaching, interest in teaching and teaching experience of job commitment of primary school teachers. M. Ed Thesis. 2007.

16. Parvez M, Shakir M. Attitudes of prospective teachers towards teaching profession. J Educ Pract 2013; 4:172-8.

17. Akkaya F. Pre-service teachers' attitude towards teaching profession. Inonu Uni J Fac Edu 2009; 9:27-42.

18. Bozdogan AE, Aydin D, Yildirin K. Teachers' attitudes toward teaching profession. Kireehir J Edu 2007; 8:83-97.

19. Chakraborty A, Mondal BC. Attitude of prospective teachers towards teaching profession. Am J Soc Sci 2014; 2:120-5.

20. Capa Y, Cil N. Teachers' attitudes towards teaching profession: An investigation of the different variables. Hacettepe Uni J Edu 2000; 18:69-73.

21. Osunde AU, Izevbigie TI. An assessment of teachers' attitude towards teaching profession in midwestern Nigeria. Education 2006; 126:462-8.

22. Popescu D. Active learning in the university teaching environment. Analele Universitatii" Constantin Brancusi" din Targu Jiu. Serie Litere si Stiinte Sociale 2015; 1:44.

23. Bhargava A, Pathy MK. Attitude of student teachers towards teaching profession. Turkish Online J Dist Edu 2014; 15:27-36.

24. Rani MR. Attitude towards teaching profession of prospective teachers in relation to certain demographic variables. Bhartiyam Inter J Edu Res 2016; 6:7-16. 